\title{
MOTIF FLORA DAN FAUNA DALAM \\ SULAMAN KELINGKAN KELANTAN \\ BERDASARKAN PENDEKATAN ESTETIKA \\ SENI MELAYU
}

\section{(Flora and Fauna Motifs in the Kelantan Kelingkan Embroidery Based on Aesthetic Approach of Malay Arts)}

Maizira Abdul Majid*

maizira@um.edu.my

Norhayati Ab. Rahman

yati@um.edu.my

Jabatan Kesusasteraan Melayu, Akademi Pengajian Melayu, Universiti Malaya.

Pengarang koresponden (Corresponding author): *

Sila rujuk: Maizira Abdul Majid \& Norhayati Ab. Rahman. (2022). Motif flora dan fauna dalam sulaman kelingkan berdasarkan pendekatan Estetika Seni Melayu. Melayu: Jurnal Antarabangsa Dunia Melayu, 15(1), 117-136. http://doi.org. 10.37052/jm.15(1) no5

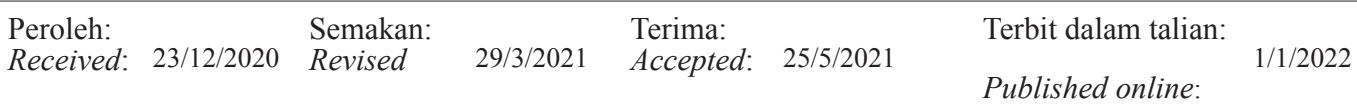

\begin{abstract}
Abstrak
Sulaman kelingkan Kelantan merupakan ciptaan seni busana Melayu sejak zamanberzaman. Penerapan pelbagai motif flora dan fauna menggunakan sulaman benang emas dan perak dalam kelingkang menjadikan kelingkan busana yang indah dan eksklusif. Artikel ini bertujuan untuk mengenal pasti kehadiran motif flora dan fauna dan fungsinya, serta menganalisis unsur keindahan flora dan fauna dalam seni sulaman kelingkan menggunakan Pendekatan Estetika Seni Melayu gagasan Zakaria Ali (1989). Kajian ini menggunakan dua kaedah utama, iaitu kaedah kajian kepustakaan dan kaedah kajian lapangan dengan menemu bual pengamal atau pakar penyulam kelingkan khususnya di negeri Kelantan. Kaedah tinjauan juga dilakukan
\end{abstract}

(C) Dewan Bahasa dan Pustaka. 2022. This work is licensed under the term of the Creative Commons Attribution (CC BY) (http://creative commons.org/licenses/by/4.0/)

ISSN 1675-6460 e-ISSN 2682-8049 
terhadap proses pengendalian bengkel sulaman kelingkan yang dilaksanakan di Kompleks Kraf Negara, Jalan Conlay Kuala Lumpur. Kajian ini menggunakan prinsip Pendekatan Estetika Seni Melayu untuk membuat analisis terhadap penggunaan motif flora dan fauna bagi memperlihatkan nilai keindahannya. Dapatan kajian menunjukkan sulaman kelingkan Kelantan telah menerapkan motif flora dan fauna sejajar dengan enam prinsip dalam Pendekatan Estetika Seni Melayu. Nilai keindahan dan estetika yang diperlihatkan melalui penerapan motif flora dan fauna dalam seni kelingkan Kelantan mempamerkan keunikan dan keistimewaan pemikiran bangsa Melayu itu sendiri dalam penghasilan seni busana Melayu.

Kata kunci: motif flora, motif fauna, kelingkan Kelantan, sulaman, seni busana Melayu, estetika seni Melayu

\begin{abstract}
The Kelantan kelingkan embroidery has been a creation of Malay art of fashion for ages. The application of various motifs of flora and fauna using gold and silver thread embroidery makes kelingkan a beautiful and exclusive clothing. This article aims to identify the presence of the various flora and fauna motifs and its functions, as well as analyze the elements of the flora and fauna in the art of kelingkan embroidery using the Aesthetic Approach to Malay Arts by Zakaria Ali (1989). This study used two main methods, namely library research and field research, by interviewing practitioners or experts in kelingkan embroidery, especially in the state of Kelantan. The observation method was also used for the operation of the kelingkan embroidery workshop that is implemented at the National Craft Complex, Jalan Conlay, Kuala Lumpur. This study focused on the principles of the Aesthetic Approach to Malay Arts to analyze the use of flora and fauna motifs in order to highlight the Malay values of beauty. The findings suggest that Kelantan kelingkan embroidery has implemented motifs of flora and fauna in line with the six principles of the Aesthetic Approach to Malay Arts. The values of beauty and aesthetics that are shown through the implementation of flora and fauna motifs in the art of Kelantan kelingkan showcase the uniqueness and distinctiveness of the Malay thought itself in the production of traditional Malay art of fashion.
\end{abstract}

Keywords: Flora motif, fauna motif, Kelantan kelingkan, embroidery, Malay art of fashion, Malay art aesthetics 


\section{PENDAHULUAN}

Sejarah telah mencatatkan bahawa wanita Melayu zaman dahulu sudah menerapkan unsur keislaman dalam pembuatan kesenian menggunakan motif flora dan fauna yang diolah menjadi abstrak. Flora boleh didefinisikan sebagai tumbuh-tumbuhan yang wujud di sesuatu tempat dan waktu. Tumbuh-tumbuhan memainkan peranan yang sangat penting dalam kelestarian kehidupan terhadap makhluk atau hidupan yang lain. Oleh yang demikian, sejak dahulu lagi tumbuh-tumbuhan sering digunakan sebagai motif yang dominan atau sumber utama maklumat dan ilham terutamanya kepada pereka dan tukang buat motif Melayu (Siti Zaiton, 1986). Sifat tumbuhan yang lembut membuktikan keharmonian kehidupan manusia dan hubungannya dengan alam sekeliling, di samping memperlihatkan unsur-unsur menyintai dan menghargai alam sekeliling (Abd. Rashid, 2014). Masyarakat Melayu juga percaya dengan elemen alam. Mereka percaya bahawa alam dan tumbuh-tumbuhan mempunyai kepentingan dan logik yang tersendiri sebagai simbol. Motif bunga misalnya menjadi simbol kepada makna tertentu dalam kehidupan mereka. Antara lain, bunga-bungaan sering digunakan sebagai simbol alam dan ketuhanan. Peletakan visual bunga dalam seni sulaman membantu memancarkan ketenangan, kehalusan, perasaan dan emosi yang segar, prinsip hidup dan keyakinan kepada Allah, manakala kelopak bunga pula menjadi lambang kepada kehidupan manusia. Sebagai manusia, kehidupan yang diberikan ialah keyakinan, ketulenan, kekuatan dan aturan sosial. Menurut Syed Ahmad Jamal (1995), konsep keindahan fizikal boleh dilihat dari mata yang memandang, namun keindahan dalam dalaman hanya boleh ditanggap daripada hati orang yang matang.

Seni sulaman kelingkan Kelantan merupakan salah satu hasil tenunan tradisional masyarakat Melayu yang sangat tinggi nilainya. Seni kemahiran tangan yang telah lama wujud ini begitu dikenali terutamanya dalam kalangan kaum wanita yang sangat komited dengan hiasan sulaman seperti pada hujung selendang, pakaian, barangan hantaran dan sebagainya. Penggunaan kain kelingkan yang kebiasaannya dipakai oleh golongan wanita terutamanya oleh golongan istana ini memerlukan kerja tangan yang sangat khusus dan rapi dari segi pembuatannya. Kain ataupun selendang kelingkan ini dahulunya hanya dipakai oleh kerabat diraja dan bangsawan. Namun begitu, kini kelingkan dimodenkan menjadi hiasan tudung, pelapik dulang, tampuk bantal, malah turut dipakai sebagai layah bagi pengantin wanita. Pemakaian selendang bersulam emas menjadi suatu tradisi bagi kaum wanita, khususnya golongan istana sama ada semasa menghadiri majlis keramaian adat, majlis pertunangan, perkahwinan ataupun semasa majlis khatam al-Quran berlangsung. Dari segi sejarahnya, penggunaan kain kelingkan dikatakan pada awalnya bertapak di Johor, Selangor dan Sarawak. Penggunaannya seterusnya berkembang sehingga ke negeri-negeri di Pantai Timur 
seperti Kelantan dan Terengganu. Penghasilan kain kelingkan yang unik dan istimewa ini tidak menggunakan peralatan canggih. Oleh itu, ketelitian dan kesabaran yang tinggi amat diperlukan semasa proses penghasilannya.

Estetika seni rupa Melayu ialah apresiasi atau penghargaan terhadap sesuatu yang cantik dan indah pada seni rupa Melayu itu sendiri. Estetika seni rupa Melayu merupakan satu bidang falsafah yang cuba menjelaskan peraturan dan prinsip keindahan, seterusnya menyelami apakah yang memandu orang-orang Melayu untuk melabelkan sesuatu sebagai indah atau cantik (Rahmah \& Nor Azlin, 2002). Menurut Ku Zam Zam (1989), kayu ukur untuk menanggapi sesuatu karya itu sebagai indah dan sempurna hanya apabila mempunyai tiga ciri, iaitu kehalusan, keaslian dan kesesuaian. Zakaria Ali (1989) pula menggariskan sifat estetika seni rupa Melayu berdasarkan enam prinsip, iaitu halus, berguna, berlambang, bersatu, berlawan dan bermakna, yang dapat dijelaskan seperti prinsip yang berikut:

1. Prinsip Halus - makna ini dapat dimengertikan hanya sesudah diketahui apakah yang tidak halus dan apakah yang kasar. Masyarakat Melayu cenderung mengira kasar sebagai sifat yang ada atau tidak ada pada tingkah laku manusia. Objek seni yang dinilai dari prinsip ini adalah berdasarkan dua faktor, pertama, cara pembuatan dan kedua, kejujuran pada bahan (1989:212).

2. Prinsip Berguna-objek seni dibuat bertujuan bukan hanya sekadar untuk mendapatkan satu objek yang sedap dipandang, atau selesa dipegang. Sebagai objek yang berfungsi, objek seni dibuat sebagai sebahagian daripada satu keseluruhan. Lazimnya objek seni dibuat bukan hanya untuk digunakan oleh seorang sahaja, tetapi digunakan oleh orang lain juga. Sikap berkongsi sebegini mencerminkan falsafah egalitarianisme, iaitu faktor yang menmpengaruhi seniman apabila berkarya.

3. Prinsip Bersatu - daripada sekuntum sehingga serumpun mawar, daripada sehelai sehingga sepohon daun, daripada sebiji sehingga setangkai buah, daripada sedaun tingkap sehingga sebuah istana, dari hulu hingga ke sarung keris, daripada huruf alif sehingga huruf ya, rasa yang dipercikkan oleh objek seni ialah rasa bersatu; rasa kesatuan.

4. Prinsip Berlawan - ini diertikan sebagai adanya pertentangan yang terkawal antara dua atau lebih jenis permukaan (1989:218).

5. Prinsip Berlambang: Lambang ialah faktor yang menentukan penyatuan antara isi dan bentuk. Prinsip berlambang atau simbol ini menekankan kesatuan antara 
isi dan bentuk. Oleh itu, orang Melayu yang kaya dengan pemikiran dan falsafah melihat hal ini sebagai suatu tanggungjawab dalam terus menyumbang kepada sesuatu yang bermanfaat sekali gus saling mengingatkan antara satu sama lain tentang kehidupan ini. Selain mempunyai maksud tersembunyi dalam setiap motif, nama-nama motif yang diberikan berkait rapat dengan simbol kehidupan.

6. Prinsip bermakna - makna sesuatu objek seni wujud secara intrinsik dan ekstrinsik. Intrinsik merujuk unsur dalaman pada motif yang digunakan, sementara ekstrinsik memerlukan kefahaman yang berhubung dengan elemen luaran yang berkaitan dengan objek seni seperti penyulam, sejarah asal usul, dan peranannya dalam masyarakat.

\section{PERMASALAHAN KAJIAN}

Kajian menunjukkan bahawa dokumentasi tentang aktiviti sulaman kelingkan Kelantan di Muzium Negeri Kelantan telah musnah ditelan banjir kuning yang melanda negeri Kelantan pada tahun 2014. Oleh yang demikian, kini tiada sebarang dokumentasi mengenainya di Muzium Negeri Kelantan untuk dijadikan rujukan oleh para pengkaji atau generasi umum yang berminat dengan sulaman warisan tradisi ini. Hasrat untuk melestarikan khazanah seni budaya warisan negeri Kelantan memerlukan usaha pendokumentasiannya. Pendokumentasian unsur adat dan budaya ini sangat berharga kepada masyarakat negeri Kelantan khususnya dan seluruh masyarakat umumnya. Oleh itu, artikel ini dikemukakan sebagai satu daripada usaha bagi melestarikan pengetahuan tentang jenis, motif sulaman kelingkan, dan falsafah di sebaliknya. Kajian ini juga bertujuan untuk menyebarkan maklumat dan pengetahuan tentang khazanah yang menjadi warisan jati diri masyarakat, yang didukung oleh pihak istana dan rakyat negeri Kelantan sejak zaman-berzaman. Seni sulaman kelingkan ini mendapat perhatian pihak istana negeri Kelantan melalui pemakaiannya oleh raja-raja perempuan. Seni sulaman kelingkan melambangkan adat dan budaya pemakaian, yang melambangkan keunggulan wanita Kelantan, bermula daripada golongan atasan sehinggalah orang kebanyakan. Oleh itu, tulisan ini berhasrat untuk membudayakan dan melestarikan khazanah warisan yang berharga tersebut, di samping untuk menyebarluaskan ilmu dan nilai falsafah yang tersurat dan tersirat melalui penciptaan dan pemakaian sulaman kelingkan dalam seni busana Melayu di Kelantan. 


\section{OBJEKTIF KAJIAN}

Kajian tentang motif flora dan fauna dalam seni sulaman kelingkan Kelantan dari Pendekatan Estetika Seni Melayu mempunyai objektif seperti yang berikut:

1. Mengenal pasti kehadiran motif flora dan fauna dan fungsinya dalam seni sulaman kelingkan negeri Kelantan.

2. Menganalisis unsur-unsur keindahan flora dan fauna dalam seni sulaman kelingkan menggunakan Pendekatan Estetika Seni Melayu.

\section{KAEDAH KAJIAN}

Bagi tujuan pemerolehan data, kajian ini menggunakan dua kaedah utama, iaitu kaedah kajian kepustakaan dan kedua kaedah kajian lapangan dengan menemu bual pengamal atau pakar dalam penyulaman kelingkan di beberapa daerah terbabit. Bagi kajian lapangan, beberapa orang penyulam kelingkan di Kelantan telah ditemu bual bagi mendapatkan maklumat tentang data kajian. Data kajian yang digunakan dalam penulisan ini ialah koleksi peribadi Nik Rahimah Nik Idris dan Nik Marhamah Nik Megat, dua orang penyulam kelingkan negeri Kelantan. Di samping itu, kaedah tinjauan juga dilakukan terhadap proses pengendalian demonstrasi sulaman kelingkan yang dikendalikan oleh Adiguru Kraf, iaitu Nik Rahimah Nik Idris dan pembantunya, Nik Marhamah Nik Megat. Demonstrasi tersebut telah dilaksanakan di Kompleks Kraf Negara, Jalan Conlay Kuala Lumpur, pada pada 6 Mac 2020. Bagi tujuan penganalisisan data, kajian ini menggunakan Pendekatan Estetika Seni Melayu oleh Zakaria Ali, yang menganalisis penggunaan motif flora dan fauna bagi memperlihatkan nilai keindahannya.

\section{DAPATAN DAN PERBINCANGAN}

Pada umumnya motif ialah elemen dekoratif dalam objek seni, termasuklah sulaman kelingkan Kelantan. Motif direka bentuk daripada corak geometri dan mempunyai susunan serta teknik tertentu. Motif dengan corak dan susunannya menjadikan sulaman kelingkan Kelantan sejenis seni kraf tangan Melayu yang sangat istimewa, bukan sahaja kerana dilakar pada kain yang cantik tetapi juga pada nilai-nilai estetika, di samping mempunyai maksud tersirat di dalamnya. Hubungan akrab antara masyarakat Melayu tradisi dengan hidupan alam semula jadi terutama alam flora dan fauna telah wujud sejak sekian lama. Keharmonian yang wujud dalam 
hubungan tersebut akhirnya menjelmakan cara hidup dan membina khazanah berasaskan ciri-ciri kosmologi. Cara pandang hidup mereka tidak sahaja terbatas untuk memanifestasikan alam sebagai material dan hidupan di dalamnya tetapi juga menerapkannya dalam kehidupan seharian masyarakat (Faizal, 2017).

Untuk memahami pentingnya tudung bersulam kelingkan kepada orang Kelantan, adalah wajar untuk seseorang itu memahami tentang keindahan dan nilai estetikanya. Pada umumnya, tudung atau selendang bersulam kelingkan Kelantan merupakan hasil kraf tangan Melayu yang mempunyai nilai estetika tinggi. Ketinggian nilai tersebut dapat dilihat daripada proses awal pembuatan hinggalah apabila tudung atau selendang itu dipakai. Sulaman kelingkan Kelantan menampilkan kejelitaan dan keanggunan si pemakai selain menegaskan sifat-sifat tertentu. Seiring dengan ciri-ciri keindahan yang diteliti dalam seni tekstil Melayu, keindahan kain kelingkan Kelantan turut diteliti daripada pelbagai bentuk motif dan corak yang dihasilkan pada kain tersebut. Antara reka corak motif flora, khususnya bunga pada kain kelingkan Kelantan termasuklah bunga tabur, bunga rerama, bunga semalu, bunga melur, bunga mawar, bunga raya dan bunga kaki ayam.

\section{Prinsip Halus}

Prinsip Halus merujuk proses penilaian sesuatu objek seni berdasarkan cara pembuatan dan sifat kejujuran pada bahan pembuatan. Cara pembuatan merujuk kehalusan kerja tangan yang melibatkan pemilihan bentuk dan elemen yang diambil daripada alam sekitar. Penciptaan reka bentuk dilakar berdasarkan unsur flora dan fauna (model alam) yang bentuk-bentuknya akan ditiru dan diubah suai atau penyesuaian. Halusnya sesebuah karya itu kerana adanya penyesuaian yang jitu antara idea dengan bahan. Oleh sebab itu, proses sulaman kelingkan memerlukan ketelitian yang sangat tinggi, seperti yang dipamerkan melalui Rajah 1.

Rajah 1 di atas menunjukkan kerangka kayu atau logam digunakan sebagai pemidang, diikuti dengan telinga kain dilekatkan pada sifon (chiffon) di hujung kedua-dua belah dan dijahit pada semua sisi mengikut yang ditentukan dalam pengukuran. Kepingan kayu atau logam panjang dimasukkan ke dalam gelung kain untuk proses regangan. Jalur kain skrap atau tali panjang kemudian dimasukkan ke dalam gelung telinga kain dengan keadaan ketat atau tegang. Seterusnya kain diregangkan sebagai permulaan proses sulaman. Lukisan pada kertas keras akan diletakkan di bawah kain dan dilukis bahagian atas berdasarkan bayangan lakaran di bawah. Teknik utama yang digunakan ialah teknik sulaman tikam tembus melalui jahitan tangan, iaitu dengan cara menjahit atas permukaan kain, melapis ke bawah (bunga pada lapisan atas dan bawah adalah sama), jaluran benang kelingkan ditindan 

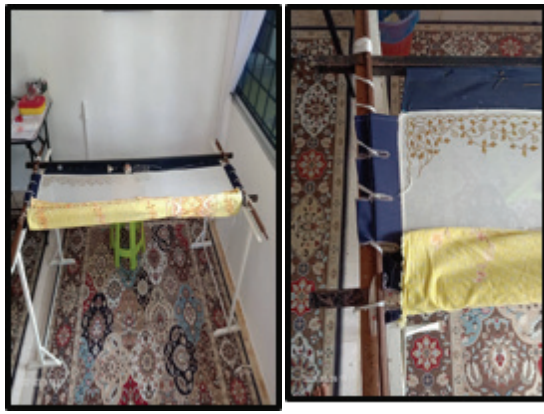

1.Pemidang
2.Kain telinga dijahit pada kain sifon.

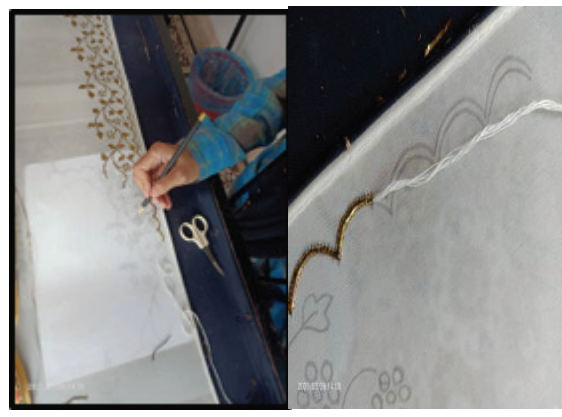

3.Melukis corak bunga pada kain.
4. Tepi kok disulam bersama empulur benang mentah.

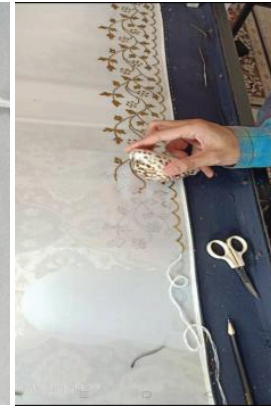

5.Gelek tindih bunga yang siap disulam menggunakan siput.

Rajah 1 Cara pembuatan sulaman kelingkan Kelantan.

kembali ke atas seterusnya membentuk motif bunga yang diperlukan. Motif terpilih dikesan di bawah kain sifon dan lakaran dibuat dengan menggunakan pensel secara berulang kali atau berterusan berdasarkan bahagian-bahagian yang telah ditandakan. Kain bersulam menggunakan benang sebagai empulur daripada benang mentah pada bahagian tepi (kok) yang diletakkan di sekeliling pemidang yang berfungsi sebagai pemegang kain. Seterusnya proses penyulaman kok diteruskan sehingga menutupi seluruh bahagian tepi kain. Motif bunga yang bertaburan tidak menggunakan empulur, hanya benang kelingkan sahaja digunakan.

Motif bunga utama atau motif sampingan disulam pada bahagian utama kain, dan setelah itu sulaman tersebut dilicinkan dengan menggunakan siput atau mentol, dalam proses yang disebut sebagai “gelek tindih." Tujuannya untuk meratakan benang sulaman supaya menjadi rata dan kemas. Semasa proses mengelek, kepingan kaca diletakkan di bawah kain untuk menahan tekanan dari atas. Seterusnya, kain yang telah siap disulam akan dilonggarkan daripada bingkai dan dikeluarkan daripada gelung, manakala kain lebihan akan dipangkas pada bahagian tepi kok. Demikian proses pembuatan kelingkan Kelantan yang menekankan aspek kehalusan dalam proses penyulamannya (pembuatan).

Aspek kehalusan sulaman kelingkan dapat dilihat pada hasil sulaman yang mengaplikasi unsur alam dalam motif sulaman. Sebagai contoh, penggunaan unsur alam seperti kulit etok dan bunga mawar (sila rujuk dalam Rajah 6), disesuaikan dan 


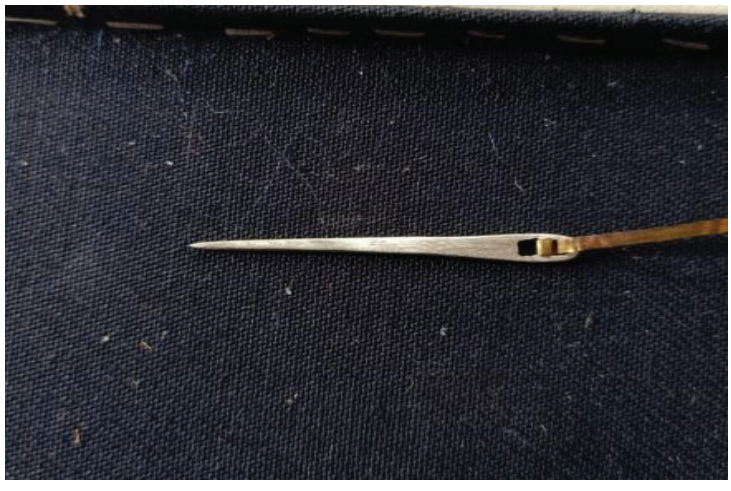

1. Jarum kelingkan

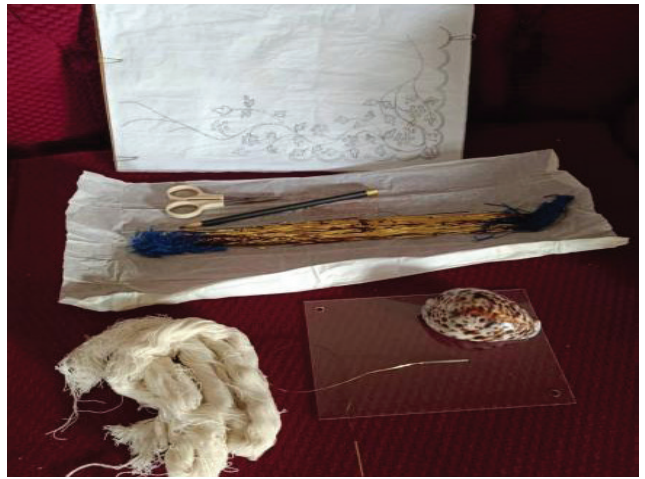

2. Pensel, kertas sureh, benang emas, benang mentah, jarum, kepingan kaca dan siput

Rajah 2 Bahan dalam sulaman kelingkan Kelantan.

dipaparkan dalam satu sulaman yang teliti dan padanan dua objek alam yang jitu. Penciptaan reka bentuk hasil kombinasi kulit etok dan bunga mawar, iaitu berdasarkan unsur flora dan fauna (model alam), memperlihatkan kehalusan sesebuah karya hasil akhir sulaman kelingkan Kelantan.

Aspek kedua dalam Prinsip Halus ialah kejujuran pada bahan yang dicerminkan melalui pemilihan dan penggunaan bahan. Seni sulaman kelingkan di Kelantan yang bernilai tinggi hanya menggunakan bahan terpilih dan berkualiti seperti Rajah 2. Rajah 2 di atas menunjukkan bahan yang digunakan seperti kepingan logam pipih bersadur emas sebagai asas utama, manakala benang yang digunakan dalam sulaman kelingkan Kelantan ialah benang perak atau benang emas. Benang yang ditempah khas tersebut berharga sehingga RM150 seikat. Benang yang dilapisi emas atau perak, biasanya daripada jenama pistol atau cap lori. Jarum kelingkan khas pula ditempah daripada tukang perak, iaitu jarum pipih bermata dua yang berfungsi untuk memasukkan dan mematikan kepingan logam di bahagian hujung kerana benang kelingkan agak berat dan licin. Jarum perak yang digunakan berukuran 4 $\mathrm{cm}$ sebanyak $2 \mathrm{~mm}$, dengan kepalanya berbentuk rata dan hujungnya tirus. Sulaman kelingkan memerlukan bahan utama seperti kayu pemidang yang digunakan untuk merenggangkan kain. Jarum, benang kelingkan, benang mentah, siput, kaca, dan kain sifon, yang digunakan sebagai asas dalam sulaman kelingkan. Pensel digunakan untuk melakarkan corak motif pada atas kain, dan sebelumnya kepingan kertas tebal digunakan untuk melakar corak motif. Benang mentah atau empulur pula digunakan 
pada garis corak di tepi kain sebelum proses penyulaman dilaksanakan dengan menggunakan benang kelingkan. Pada masa yang sama, potongan logam digunakan untuk menahan tekanan dari atas. Sehelai tudung kelingkan yang telah siap disulam akan dilipat di dalam gulungan kertas sureh dan disimpan di dalam kotak. Demikian Prinsip Halus merujuk proses penilaian sesuatu objek seni berdasarkan cara pembuatan dan sifat kejujuran pada bahan pembuatan seperti yang dibincangkan di atas.

\section{Prinsip Berguna}

Prinsip berguna menjelaskan objek seni yang berfungsi, dicipta sebagai sebahagian darpada keseluruhan. Objek seni dibuat bukan untuk digunakan oleh seorang sahaja, sebaliknya orang lain juga turut boleh menggunakannya. Sikap berkongsi yang mencerminkan falsafah egalitarianisme ini adalah antara faktor yang mempengaruhi seniman apabila berkarya. Dalam konteks ini, dapat dilihat pada aspek pemakaian kelingkan seperti yang dijelaskan di bawah.

Rajah 3 memaparkan contoh cara dan kaedah pemakaian kelingkan oleh wanita Kelantan. Antara fungsi pemakaian kelingkan adalah untuk melambangkan prestij pemakainya kerana pada kebiasaannya kelingkan dipakai oleh wanita golongan diraja atau bangsawan. Walau bagaimanapun, pada hari ini pemakaian kelingkan
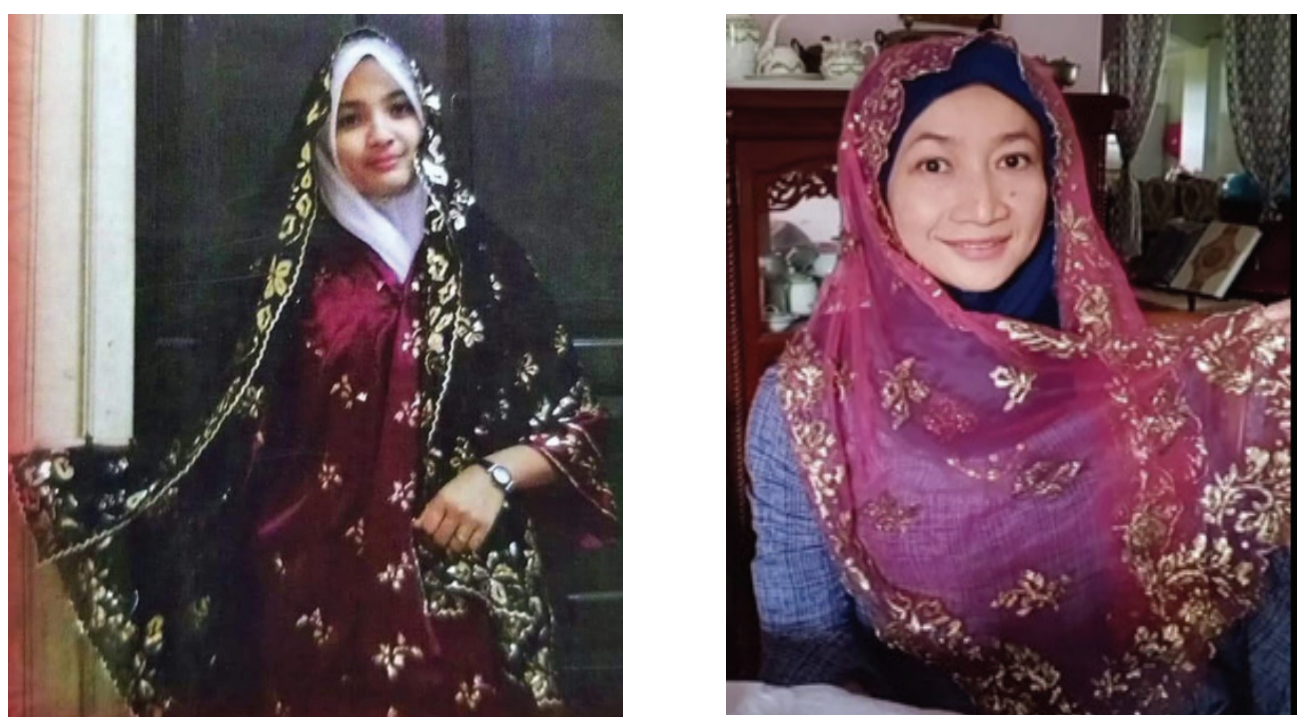

Rajah 3 Pemakaian Kelingkan oleh Nik Nurul Amalina dan Nik Marhamah. 
telah tersebar kepada orang kebanyakan. Tudung kelingkan terutamanya dipakai untuk menyerikan majlis tertentu seperti perkahwinan, pertunangan, khatam Quran, dan seumpamannya. Pemakaian kelingkan oleh seseorang wanita berupaya menaikkan seri dan aura si pemakai, sekali gus memberikan nilai keindahan kepada khalayak dalam sesuatu majlis. Gambaran ini menunjukkan bahawa Prinsip Berguna dalam Pendekatan Estetika Seni Melayu tidak terhad pada sesuatu kelompok tertentu sahaja, sebaliknya sesuatu objek seni itu boleh digunakan dan dinikmati oleh semua lapisan masyarakat.

\section{Prinsip Bersatu}

Pada sesebuah karya dikatakan ada mula dan ada akhir atau setidak-tidaknya dapat dicari permulaan dan pengakhirannya. Konsep bersatu umumnya terhad pada unitnya sendiri. Perkaitan dan intergrasi wujud, khususnya di antara dan di dalam unit tersebut. Jelaslah bersatu ialah soal perkaitan (1989:218). Hal ini bererti perkaitan antara bahagian-bahagian yang berbeza kedudukannya, seperti yang di luar dan yang di dalam. Prinsip bersatu memperlihatkan adanya perkaitan dan intergrasi di antara dan di dalam unit sesebuah motif tertentu. Bagi menjelaskan prinsip ini dapat dilihat pada contoh ciptaan motif bunga daun dalam Rajah 4.

Berdasarkan Rajah 4, paparan motif bunga daun yang menunjukkan proses penciptaannya bermula dengan lakaran sehelai daun. Kemudiannya diikuti dengan lakaran sulaman daun-daun lain yang akhirnya membentuk sekuntum bunga daun. Proses penciptaan motif bunga daun yang sedemikian, dilakukan secara berulangulang sehingga akhirnya membentuk rantaian unit-unit yang sama dalam kedudukan
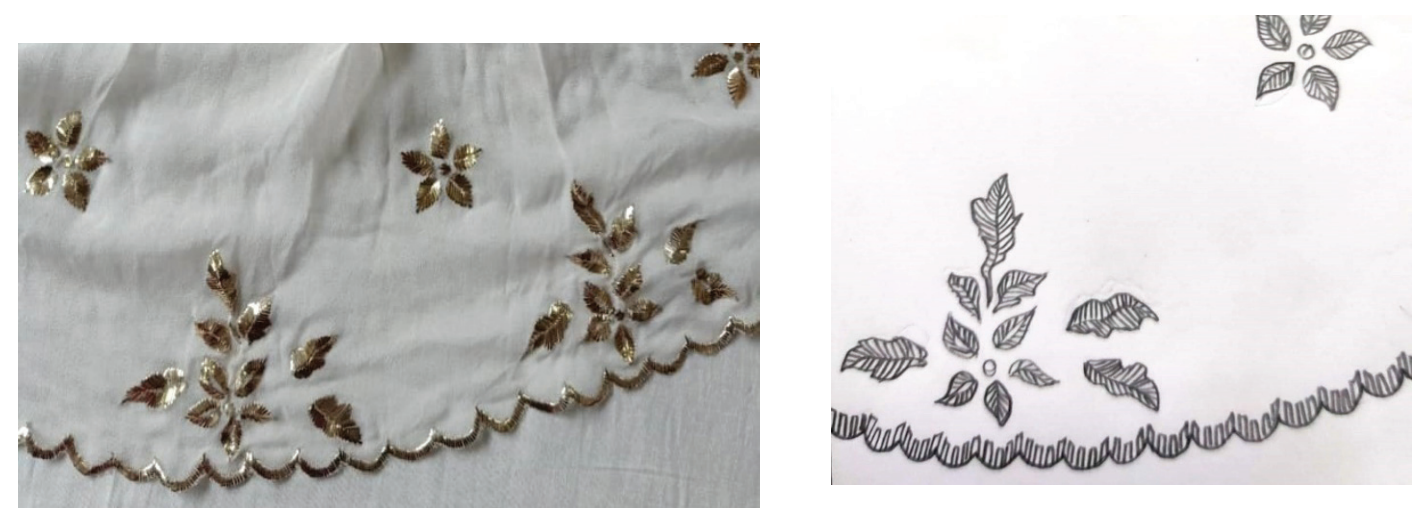

Rajah 4 Motif bunga daun. 

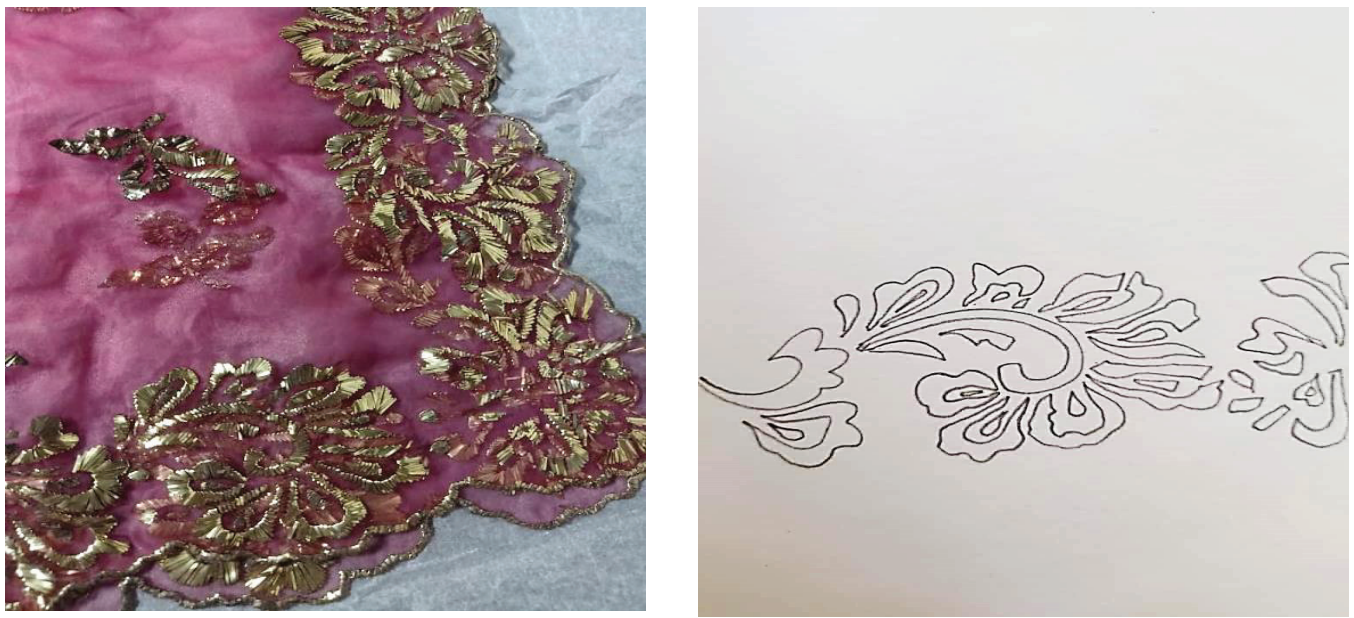

Rajah 5 Motif awan larat.

yang berjajaran, tetapi masih mengekalkan kesatuan di antara dan di dalam unit-unit bunga daun tersebut. Gambaran ini menunjukkan wujudnya perkaitan daripada motif sehelai daun menjadi sekuntum bunga daun, dengan mengekalkan kesatuannya. Sekali gus memaparkan gambaran keindahan dan kesatuan yang mencerminkan adanya permulaan dan pengakhiran dalam proses penciptaan motif tersebut. Dengan demikian, contoh motif bunga daun ini menjelaskan bahawa keindahan seni kelingkan juga dapat dikesan daripada penciptaan motif yang menjelaskan hubungannya dengan Prinsip Bersatu yang terdapat dalam Pendekatan Estetika Seni Melayu.

Prinsip bersatu juga dapat dilihat pada contoh motif dalam Rajah 5, iaitu penerapan motif awan larat. Proses penciptaan motif awan larat dihasilkan melalui penghayatan penyulam terhadap awan yang sentiasa bergerak dan melarat sehingga mewujudkan motif rekaan yang melarat atau berpanjangan, sesuatu yang berkesinambungan (Abd Rasid, 2014:43). Tompokan atau gumpalan awan (kumulus) ialah tompokan awan yang bentuk dasarnya adalah rata dan struktur atas yang kelihatan berbonggolbonggol. Kumulus bermaksud timbunan atau gumpalan yang gebu atau berbentuk seperti kapas. Unit ini didapati wujud secara bersendirian dalam satu baris, sebelum berlakunya pergerakan unit-unit ini lalu membentuk satu gugusan awan, dalam satu kesatuan. Proses tersebut memberikan nilai keindahan dan kesatuan yang mencerminkan wujudnya permulaan dan pengakhiran dalam unsur alam yang akhirnya diadaptasi dalam proses penciptaan motif awan larat dalam sulaman kelingkan. Pemaparan ini juga menjelaskan kehadiran Prinsip Bersatu dalam ciptaan motif yang dilihat daripada Pendekatan Estetika Seni Melayu. 


\section{Prinsip Berlawan}

Prinsip ini menjelaskan tentang wujudnya pertentangan yang terkawal antara dua atau lebih jenis motif yang dicipta dalam seni sulaman kelingkan, seperti yang huraian yang berikutnya.

Rajah 6 menunjukkan reka corak motif flora dan fauna yang mengandungi elemen yang berlawanan, seperti yang dinyatakan dalam Prinsip Berlawan berdasarkan Pendekatan Estetika Seni Melayu. Dalam konteks penciptaan motif sulaman kelingkan Kelantan, prinsip berlawan (kontradik) ini dapat dilihat pada contoh penggunaan atau penerapan motif yang terdiri daripada alam flora dan fauna, iaitu motif bunga mawar (sejenis flora yang tumbuh di atas tanah atau di daratan), digabungkan dengan motif kulit etak (sejenis fauna yang hidup di sungai atau di dalam air). Dua elemen yang berbeza yang hidup dalam habitat berbeza, di darat dan di dalam air. Walau bagaimanapun, kewujudan perbezaan daripada prinsip berlawan ini dapat dikurangkan dengan cara penyusunan motif yang akhirnya dapat memperlihatkan keharmonian.

Selain itu, aspek berlawan juga dapat dilihat pada timbulan sulaman di permukaan kain secara dominan. Timbulan yang menampilkan dua motif berlawanan, iaitu kulit etak dan bunga mawar, menyerlahkan permukaan kain dengan sulaman kelingkan. Penampilan tersebut semakin timbul dan menyerlah dengan penggunaan dua warna
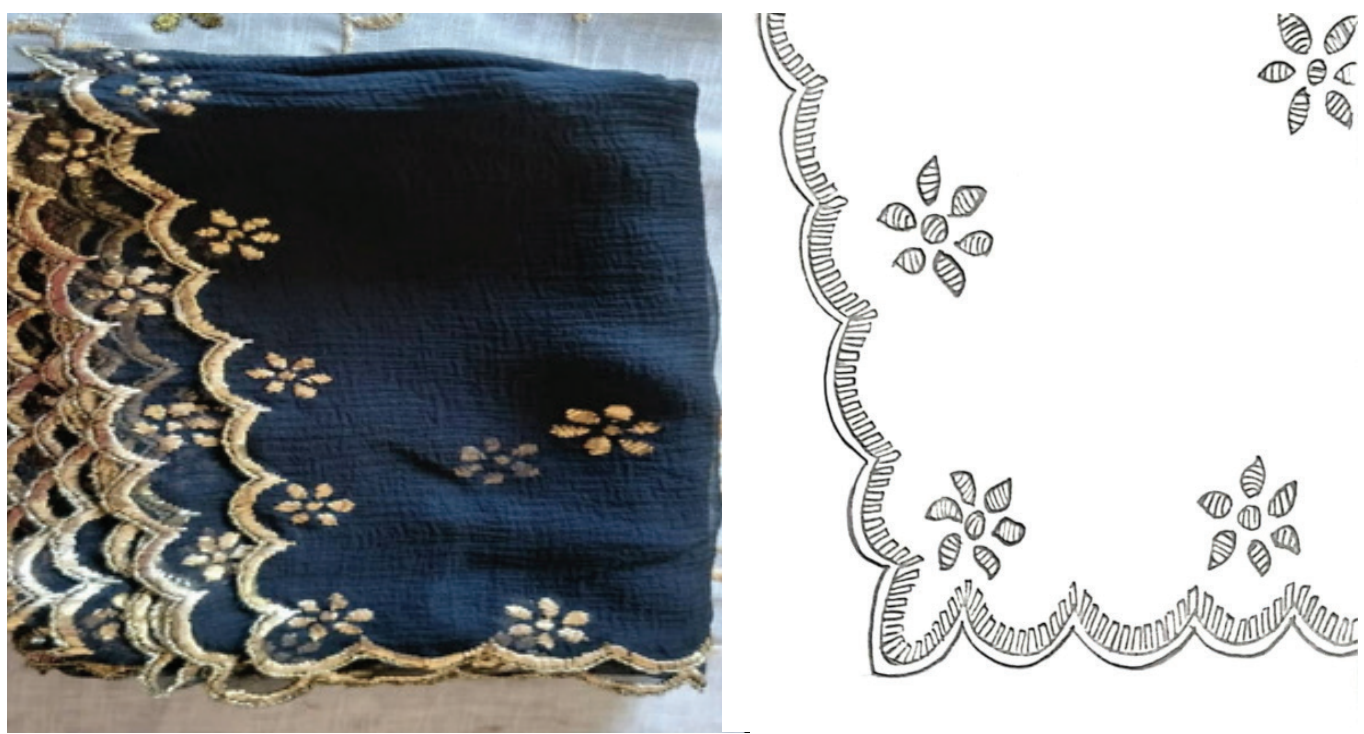

Rajah 6 Motif kombinasi kok Kulit Etak dan Bunga Mawar. 
yang kontradik, iaitu warna hitam pada kain dan warna emas pada motifnya. Di samping itu, unsur berlawan juga diperlihatkan melalui kedudukan dan susunan motif sulaman. Penggunaan motif kulit etak yang disulam pada bahagian tepi kain (kok), disesuaikan dengan kedudukan sulaman bunga mawar pada posisi atasnya, menunjukkan wujud dua elemen yang bertentangan tetapi harmoni. Prinsip ini menunjukkan sesuatu objek seni harus mengandungi elemen yang berlawanan. Kewujudan ketegangan daripada prinsip berlawanan ini dapat disusutkan dengan memasukkan motif-motif lain bagi memperlihatkan perbezaan (kepelbagaian) tetapi harmoni.

Kaedah ini berhubung kait dengan cara orang Melayu mengawal perlawanan atau pertentangan yang disebabkan oleh ketegangan dalam kehidupan bermasyarakat. Dalam konteks ini, penggunaan motif yang berasal daripada dua entiti yang berbeza, ditemukan dan disatukan dalam satu ciptaan sulaman kelingkan yang indah. Prinsip Berlawan dalam Pendekatan Estetika Seni Melayu sebagai lambang kewujudan sifat semula jadi manusia Melayu yang suka bertentangan atau bertegang, tetapi kemudian dileraikan bagi membentuk keharmonian dalam kehidupan bermasyarakat.

Prinsip berlawan juga dapat dilihat pada contoh motif yang terdapat dalam Rajah 7, iaitu penerapan motif yang terdiri daripada alam flora dan fauna, yang terdiri daripada motif bunga mawar (sejenis flora yang tumbuh di atas tanah atau di daratan), digabungkan dengan motif gigi yu (sejenis fauna yang hidup di laut atau di dalam air).
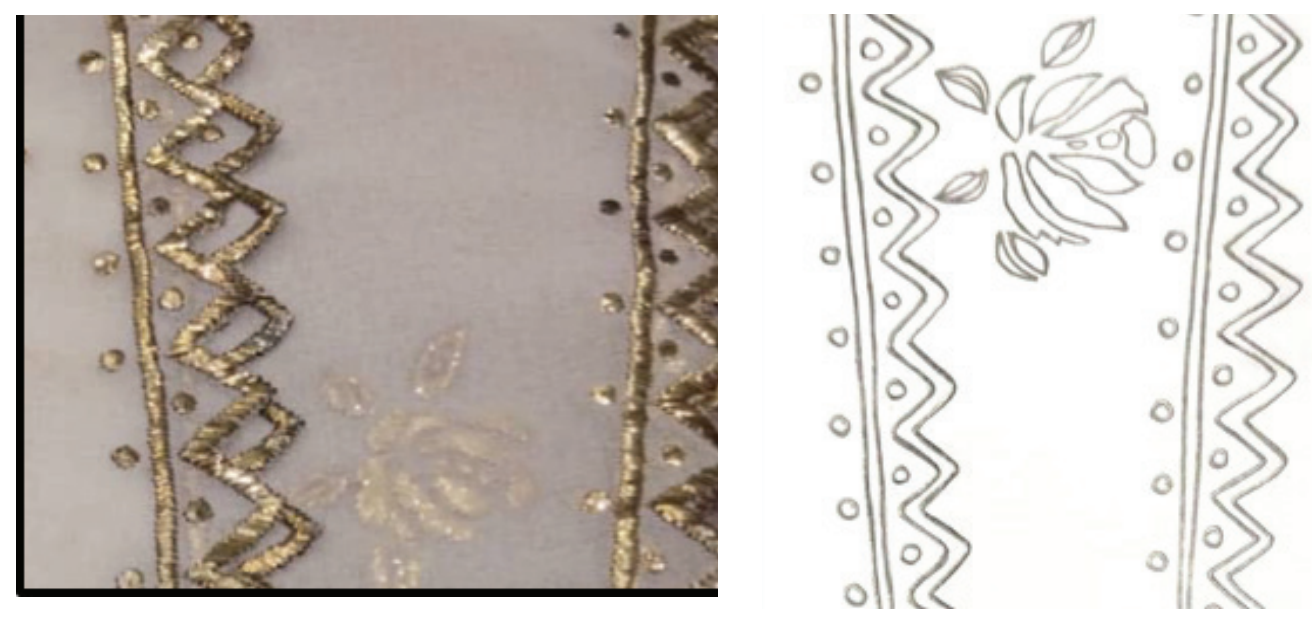

Rajah 7 Motif Gigi Yu dan Bunga Mawar. 


\section{Prinsip Berlambang}

Lambang ialah faktor yang menentukan penyatuan antara isi dan bentuk. Prinsip berlambang menekankan kesatuan antara isi dan bentuk. Orang Melayu yang kaya dengan pemikiran dan falsafah melihat hal ini sebagai suatu tanggungjawab dalam terus menyumbang kepada sesuatu yang bermanfaat sekali gus saling mengingatkan antara satu sama lain tentang kehidupan ini. Selain mempunyai maksud yang tersembunyi dalam setiap motif, nama motif yang diberikan berkait rapat dengan simbol kehidupan, seperti yang dapat dilihat pada contoh penggunaan motif dalam Rajah 8.

Rajah 8 menunjukkan reka corak motif bunga mawar yang diolah pada kain tudung kelingkan Kelantan. Bunga mawar ialah bunga yang harum, sifatnya yang cantik dan disukai oleh kebanyakan wanita. Berdasarkan Pendekatan Estetika Seni Melayu, penggunaan motif bunga mawar ini dapat dikaitkan dengan prinsip yang kelima, iaitu Prinsip Berlambang. Melalui Prinsip berlambang, nilai-nilai keindahan seni sulaman menekankan aspek kesatuan antara isi dan bentuk. Dari segi isi, penggunaan motif bunga mawar memacu kepada makna yang melambangkan kesucian, kewanitaan, kecantikan dan keteguhan peribadi seseorang wanita Melayu. Dari segi bentuk pula, sifat tersebut diperlihatkan melalui imej luaran fizikal bunga mawar yang tangkainya berduri dan sukar untuk dipetik, serta perlu amat berhatihati memetiknya supaya durinya tidak melukai jari si pemetik. Bentuk fizikal ini mencerminkan keteguhan peribadi seseorang wanita untuk mempertahankan kesucian dan maruah seorang wanita. Dalam konteks realiti kehidupan, hanya lelaki yang berani sahaja yang mampu mematahkan tangkai berduri untuk memetik
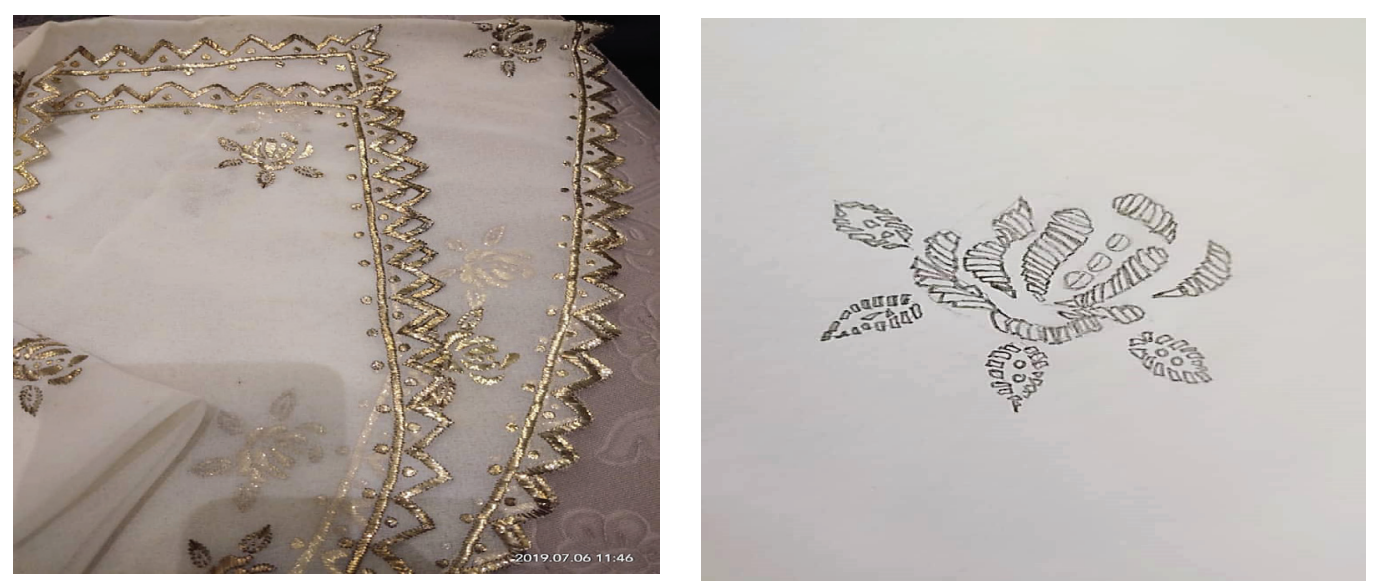

Rajah 8 Motif Bunga Mawar. 
bunga mawar (lambang wanita) tersebut. Selain itu, terdapat sejumlah pepatah Melayu yang menggambarkan kecantikan wanita ibarat bunga mawar. Masyarakat Melayu menggunakan reka corak motif bunga mawar dalam sulaman kelingkan yang menjelaskan makna prinsip berlambang seperti yang dikemukakan dalam Pendekatan Estetika Seni Melayu oleh Zakaria Ali. Penerapan prinsip berlambang juga dapat dihuraikan pada penerapan motif bunga semalu seperti yang ditunjukkan dalam Rajah 9.

Rajah 9 menunjukkan motif bunga semalu yang diaplikasikan sebagai satu motif dalam reka corak sulaman kelingkan Kelantan. Tumbuhan merayap yang melata ini mempunyai makna yang berkait rapat dengan fitrah seorang wanita. Dalam konteks ini, beberapa sifat yang terdapat pada pokok semalu memperlihatkan beberapa perkara yang sejajar dengan keperibadian seorang wanita, khususnya wanita Melayu. Antara sifat pokok semalu ialah menguncup apabila disentuh, hal ini ini boleh diibaratkan seorang wanita yang mempunyai perasaan malu (pada tempatnya). Pokok semalu juga mempunyai duri yang tajam untuk mempertahankan dirinya dan ini melambangkan seorang wanita seharusnya mengetahui cara-cara untuk mempertahankan diri dan maruah mereka agar tidak mudah tercemar. Semalu juga mempunyai akar tunjang yang kuat dan mencengkam bumi yang menjelaskan makna seorang wanita yang mempunyai keperibadian dan semangat hidup yang kuat serta sukar untuk digoyah oleh sebarang cabaran dan ujian. Pokok semalu yang akan menguncup dengan sendiri apabila menjelang waktu senja. Hal ini bemaksud
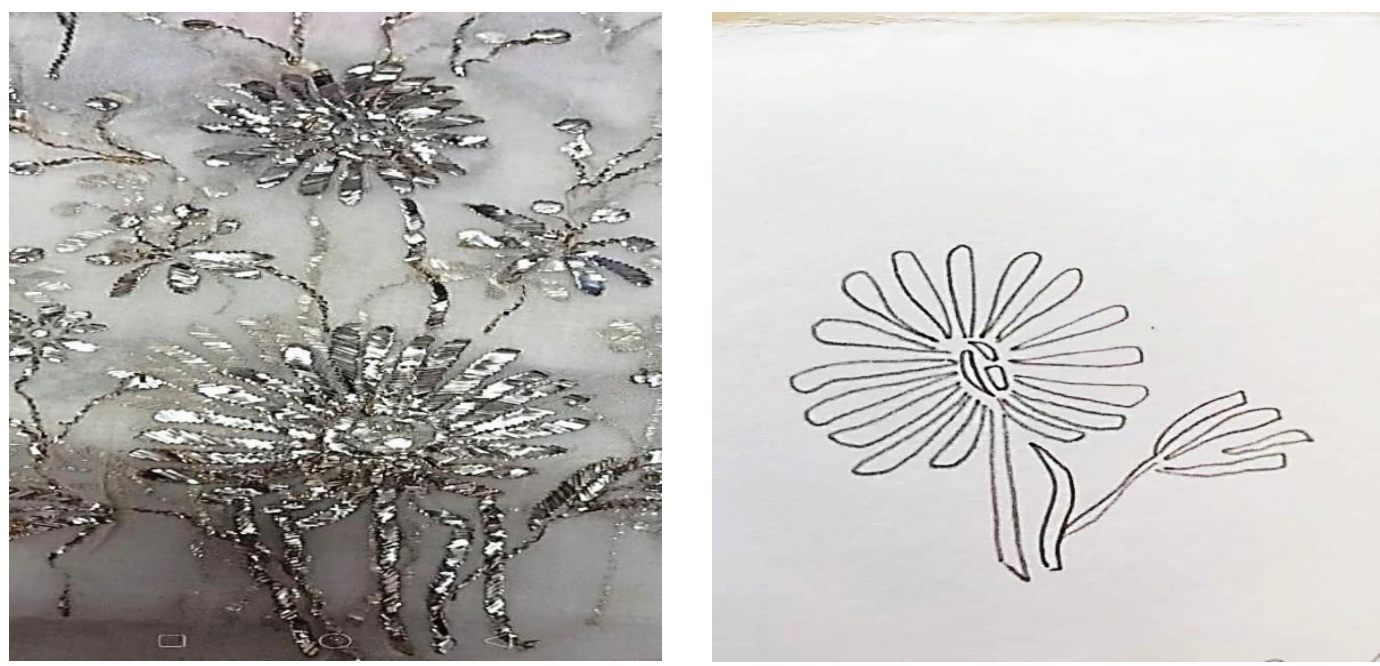

Rajah 9 Motif Bunga Semalu. 
seorang wanita harus menjaga diri dan keperibadian, serta pulang ke rumah apabila tiba waktu senja. Sifat-sifat yang ditonjolkan melalui imej tumbuhan semalu ini menjelaskan falsafah di sebalik penggunaan motifnya, terutama untuk menjelaskan peribadi dan maruah seseorang wanita yang harus dijaga serta menanamkan rasa malu dalam diri agar kesucian mereka terpelihara. Gambaran ini berhubung kait dengan makna prinsip berlambang yang dikemukakan dalam Pendekatan Estetika Seni Melayu oleh Zakaria Ali.

\section{Prinsip Bermakna}

Prinsip bermakna sesuatu objek seni wujud secara intrinsik dan ektrinsik. Intrinsik merujuk unsur-unsur dalaman pada motif yang digunakan, sementara ekstrinsik memerlukan kefahaman yang berhubungan dengan elemen luaran yang berkait dengan objek seni seperti penyulam, sejarah asal usul, dan peranannya dalam masyarakat. Dari segi intrinsik, dapat diperlihatkan melalui contoh dalam Rajah 10, yang memberikan perhatian pada unsur dalaman bagi motif Tepi Gunung 7 .

Berdasarkan contoh motif di atas, dapat dilihat unsur-unsur dalaman yang terdiri daripada kok gunung 7, bunga tabur dan posisi taburannya serta jenis-jenis bunga yang digunakan sebagai motif bunga tabur. Kok gunung 7 merujuk sulaman tepi yang berbentuk gunungan, yang disulam sebanyak 7 kali dan diakhiri dengan gunung yang lebih tinggi. Sulaman kok tersebut dibuat secara berulang-ulang sehingga sampai ke penghujung. Selain kok, unsur dalaman juga terdiri daripada motif bunga yang dinamakan bunga tabur. Bunga tabur ini boleh terdiri daripada pelbagai jenis bunga,
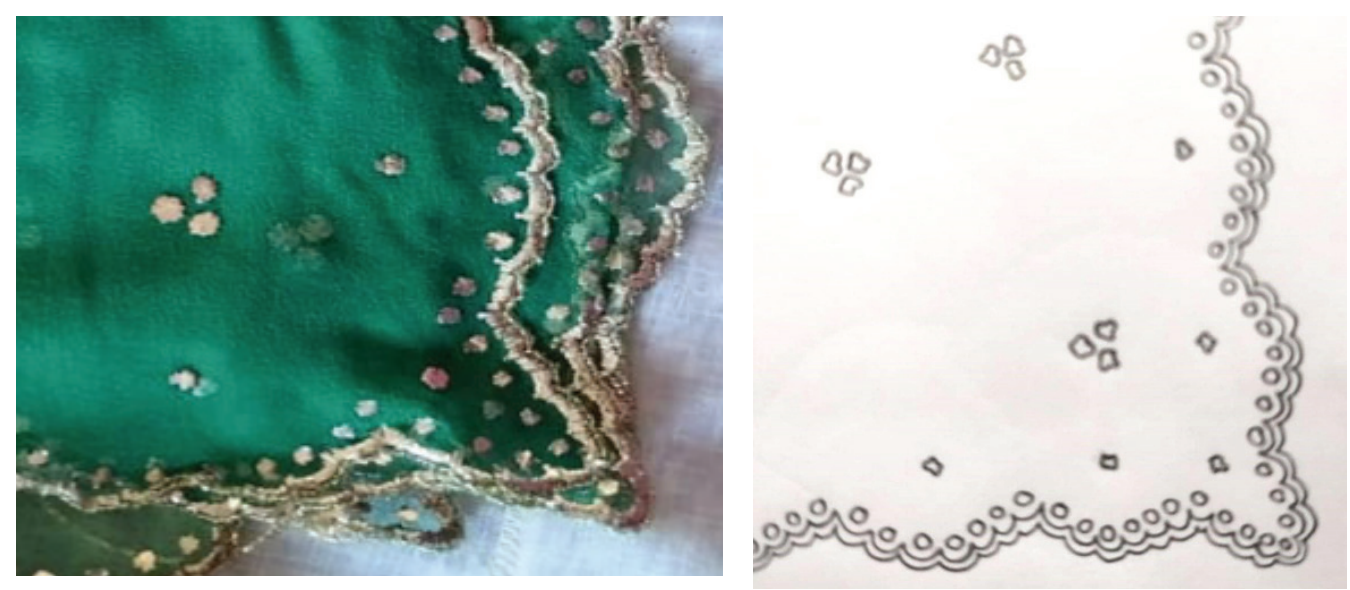

Rajah 10 Motif Tepi Gunung. 

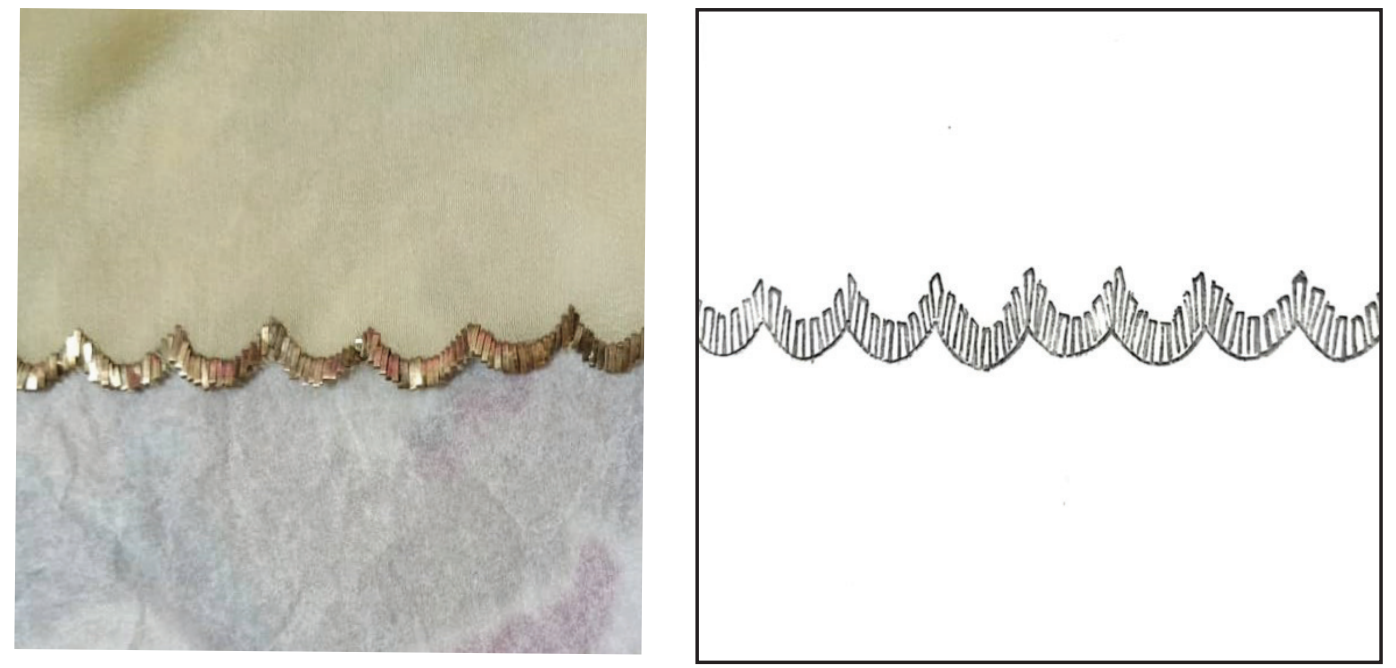

Rajah 11 Motif Kulit Etak.

termasuk bunga mawar, bunga melur, bunga raya, bunga daun dan sebagainya. Taburan tersebut diletakkan pada bahagian tertentu, seperti bahagian bucu atau penjuru, bahagian kepala atau bahagian tepi. Kombinasi penggunaan unsur-unsur alam tersebut dalam sulaman kelingkan memberikan makna keindahan kepada seni sulaman kelingkan Kelantan.

Dari segi ekstrinsik pula, antara lain kelingkan dapat dihubungkan dengan penyulam yang mempunyai daya kreativiti dan sensitiviti untuk menanggapi unsur alam dan mengadaptasinya pada motif sulaman. Selain itu, unsur ekstrinsik juga dapat dihubungkan dengan pemakaiannya oleh golongan istana sehinggalah kepada rakyat kebanyakan, yang menunjukkan keterbukaannya sebagai objek seni yang boleh dinikmati oleh sesiapa saja.

Dari sudut unsur intrinsik juga dapat dilihat pada motif kulit etak pada Rajah 11, yang terdiri daripada lakaran permukaan luar kulit etak. Etak merupakan sejenis kerang yang didapati di dalam sungai dan popular hanya di negeri Kelantan. Motif kulit etak tersebut disulam dalam keadaan tersusun, secara berulang-ulang dan berterusan dari permulaan sampai pengakhirannya, sehingga membentuk kok pada tudung kelingkan. Dari segi ekstrinsik pula, etak dikenali sebagai makanan ringan popular dalam kalangan rakyat negeri Kelantan. Etak juga menjadi sumber rezeki kepada penduduk di pinggir sungai yang "mengokok" (seperti mendulang) etak di dalam sungai, kemudian digaul dengan ramuan khusus serta dijemur atau disalai etak tersebut sebelum dijual di pasar atau di tepi-tepi jalan. Popularnya makanan 
bernama etak di negeri Kelantan sehingga imej etak ini diadaptasi sebagai motif fauna dalam sulaman kelingkan Kelantan. Hal ini sekali gus memberikan makna kepada kelingkan sebagai objek seni bersifat intrinsik dan ekstrinsik, seperti yang ditekankan oleh Prinsip Bermakna dalam Pendekatan Estetika Seni Melayu.

\section{KESIMPULAN}

Berdasarkan perbincangan terhadap motif yang diterapkan dalam sulaman kelingkan Kelantan, memperlihatkan nilai keindahan dan falsafah pemikiran masyarakat Melayu Kelantan sejak zaman-berzaman. Nama motif flora dan fauna yang digunakan seperti bunga tabur, bunga rerama, bunga semalu, bunga melur, bunga mawar, bunga raya dan bunga kaki ayam yang terdapat dalam sulaman kelingkan Kelantan membawa simbol penting yang berkait rapat dengan alam dan juga kehidupan masyarakat manusia Melayu. Bukan itu sahaja, nama-nama motif fauna yang digunakan seperti motif awan larat, gunungan, kekacang, kembangan dan gigi yu memperlihatkan simbol keterikatan masyarakat Melayu dengan alam. Daripada analisis yang dilakukan terhadap motif-motif dalam sulaman kelingkan Kelantan dengan menggunakan prinsip dalam Pendekatan Estetika Seni Melayu, membuktikan bahawa seni sulaman kelingkan Kelantan mempunyai nilai-nilai keindahan seperti yang digariskan dalam enam prinsipnya. Prinsip estetika tersebut ialah pertama; Prinsip Halus yang dapat dilihat pada cara pembuatan kelingkan dan kejujuran pada bahannya (bahan yang sepatutnya). Kedua, Prinsip Berguna yang didasarkan pada satu objek yang indah dipandang dan selesa dipakai. Ketiga, Prinsip Bersatu yang menekankan aspek ciptaan motif yang mempunyai permulaan dan pengakhiran, perkaitan dan intergrasi di antara dan di dalam unit-unit ciptaan. Ketiga, Prinsip Berlawan yang menjelaskan tentang adanya pertentangan yang terkawal antara dua atau lebih motif-motif dalam sulaman kelingkan. Keempat, Prinsip Berlambang, yang menekankan aspek penyatuan antara isi dan bentuk. Aspek isi menekankan penggunaan motif yang memacu kepada makna berbentuk perlambangan, manakala aspek bentuk pula, memperlihatkan imej luaran fizikal motif yang digunakan dalam sulaman kelingkan. Yang terakhir ialah Prinsip Bermakna, yang merujuk unsur intrinsik dan ekstrinsik pada setiap motif yang dilakar dalam sulaman kelingkan Kelantan. Oleh yang demikian, dapat dirumuskan bahawa dengan menerapkan motif flora dan fauna dalam sulaman kelingkan Kelantan, ternyata berupaya menyerlahkan lagi unsur-unsur kehalusan dan keindahannya yang dilihat berdasarkan Pendekatan Estetika Seni Melayu. 


\section{PENGHARGAAN}

Kajian ini ialah hasil penyelidikan daripada Geran Penyelidikan Fakulti (GPF004K-2018) pembiayaan dana Universiti Penyelidikan (RU) 2018, Universiti Malaya.

\section{RUJUKAN}

Abd. Rasid Ismail. (2014). Alam Sebagai motif kraftangan fabrik Melayu tradisi. Penerbit Universiti Teknologi Mara.

Faizal Sidek. (2017). Motif Songket Melayu: Pengucapan Falsafah (terjemahan). Diakses daripada http://faizalsidik.blogspot.com/2017/05/motif-songket-melayu-pengucapanfalsafah.html

Ku Zam-zam Ku Idris. (1989). Budaya Material dan Teknologi: Pertukangan Melayu. Universiti Malaya

Nor Farhani Che Ad. (2013). Sulaman kelingkan seni lama. Diakses daripada http:// seniwarisanbangsamelayu.blogspot.com/2013/04/sulaman-kelingkan-seni-lama.html

Norsa'adah Ahmad. (2019). Selendang: Kelingkan dan Keringkam. Diakses daripada http:// norsaadah.com/selendang-kelingkan-dan-keringkam/

Othman Mohd Yatim \& Arba'iyah Abd. Aziz. (2005). Kertas Kerja telah dibentangkan dalam International Symposium on Malay Songket dengan tema " Songket-The Regal Heritage of the Malay World (Songket-Warisan Agung Dunia Melayu) di Pusat Dagangan Dunia Putra, Kuala Lumpur pada 6-7 September 2005.

Othman, M. Y., Zainal Abidin, B., Mohammad Nazzri, A., \& Mohamad Anis, A. S. (2006). Estetika dan keindahan songket Melayu. Jurnal Pengajian Melayu, 17, 1-15.

Rahmah Bujang \& Nor Azlin Hamidon. (2002). Kesenian Melayu. Akademi Pengajian Melayu.

Ros Mahwati Ahmad Zakaria. (2012). Sulaman Kelingkan. Diakses daripada https:// www.ukm.my/atma/wp-content/uploads/2019/07/UMsia-190704-Warisan-KilauanSulamanKelingkan-AlamMelayu.jpg

Siti Zainon Ismail. (1986). Rekabentuk kraftangan Melayu tradisi. Dewan Bahasa dan Pustaka.

Siti Zainon Ismail. (1989). Percikan seni. Dewan Bahasa dan Pustaka.

Siti Zainon Ismail. (2010). Seni Sulaman Kelingkan-Keringkam. Diakses daripada https:// SENI RUPA ALAM MELAYU: Seni Sulaman Kelingkan - Keringkam (senirupasiti. blogspot.com.

Suhana Sarkawi dan Norhayati Ab. Rahman. (2020). Jejak Sulaman Kelingkan di Malaysia dan Indonesia. Jurnal Pengajian Melayu (JOMAS), 27(1), 45-69.

Syed Ahmad Jamal. (1992). Rupa dan Jiwa. Dewan Bahasa dan Pustaka.

Zakaria Ali. (1989). Seni dan seniman: Esei-esei halus. Dewan Bahasa dan Pustaka. 